\title{
PENERAPAN MODEL PEMBELAJARAN ARIAS TERINTEGRASI PENDEKATAN PROBLEM BASED INSTRUCTION UNTUK MENINGKATKAN AKTIVITAS DAN HASIL BELAJAR PADA MATERI SISTEM PERSAMAAN LINEAR TIGA VARIABEL KELAS X MIA MAN 1 BANJARMASIN
}

\author{
Yuliastono Budi Prakasa \\ Madrasah Aliyah Negeri 1 Banjarmasin \\ e-mail: yuliastonobudi@gmail.com \\ Website : https://jurnal.uin-antasari.ac.id/index.php/ptkpend/index \\ Received: Januari 2020; Accepted: Februari 2020; Published: Februari 2020
}

\begin{abstract}
This research aims to find out how teacher activity and student responses about implementation of integrated ARIAS learning model for problem based instruction approach. This research design was used classroom action research which consisted two cycles with four phases; planning, action, evaluation and reflection. The subject were 25 students. Data collection was used by observation techniques, written tes and questionnaires. Then, data were analyzed by quantitatively and qualitatively techniques. The research result showed that there was an increase in teacher's activity from 88 at cycle I to 113,5 at cycle II, an increase in student's study activity from 16,88 at cycle I to 22,72 at cycle II, an increase in student's achievement from 61,40 at cycle I to 80,10 at cycle II and student give good response for learning which integrated ARIAS learning model for the problem based instruction approach.
\end{abstract}

Keyword: ARIAS; problem based instruction; teacher's activity; student's study activity; student's achievement.

\section{ABSTRAK}

Penelitian ini bertujuan untuk mengetahui bagaimana aktivitas guru dan respon siswa terhadap penggunaan model pembelajaran ARIAS terintegrasi pendekatan Problem Based Instruction. Penelitian ini menggunakan rancangan penelitian tindakan kelas (PTK) dengan 2 siklus. Masing-masing siklus terdiri dari tahap perencanaan, pelaksanaan tindakan, observasi dan evaluasi, serta analisis dan refleksi. Subjek dalam penelitian ini adalah siswa kelas X MIA 3 dengan jumlah siswa sebanyak 25 orang. Data yang dikumpulkan menggunakan teknik observasi, tes tertulis dan angket. Selanjutnya data tersebut dianalisis dengan teknik analisis deskriptif kuantitatif dan analisis kualitatif. Hasil penelitian menunjukkan bahwa dapat terjadi peningkatan aktivitas guru dari 88 pada siklus I menjadi 113,5 pada siklus II, peningkatan aktivitas belajar siswa dari 16,88 pada siklus I menjadi 22,72 pada siklus II, peningkatan hasil belajar dari 61,40 pada siklus I menjadi 80,10 pada siklus I dan siswa memberikan respon yang baik terhadap penerapan model pembelajaran ARIAS terintegrasi pendekatan Problem Based Instruction.

Kata kunci: ARIAS; problem based instruction; aktivitas guru; aktivitas belajar siswa; hasil belajar siswa.

\section{PENDAHULUAN}

Pendidikan mempunyai peran yang penting bagi kehidupan manusia. Oleh karena itu, pendidikan harus mendapatkan perhatian dan prioritas dari semua pihak. Suatu pendidikan tidak hanya mementingkan hasil akhirnya saja, namun yang paling penting ialah prosesnya, dimana dengan proses tersebut siswa dapat memahami maksud dari proses pembelajaran yang dilakukan.Pendidikan yang berkualitas tidak terlepas dari seorang guru sebagai seorang pendidik. Guru 
diharuskan mampu menciptakan proses pembelajaran yang aktif, kreatif, inovatif, efektif dan menyenangkan.

Matematika adalah salah satu mata pelajaran yang diajarkan kepada siswa dari tingkat taman kanak-kanan hingga tingkat sekolah menengah atas bahkan hingga ke bangku perkuliahan. Hal itu karena matematika merupakan salah satu ilmu yang sangat penting apalagi di zaman sekarang yang perkembangan dan teknologi yang semakin meningkat dimana matematika dianggap sebagai salah satu ilmu dasar yang memiliki esensial yang dapat diterapkan dalam berbagai kehidupan. Matematika merupakan ilmu yang mempelajari sebuah kepastian yang menegaskan struktur abstrak, menggunakan logika simbolik dan notasi matematika.

Di lapangan, kebanyakan siswa tidak begitu menyukai pelajaran matematika. Berbagai penyebab yang membuat para siswa tidak menyukai matematika diantaranya siswa menganggap matematika adalah pelajaran yang sulit, tidak mudah dipahami karena didalamnya banyak perlu dilakukan yaitu menghafal rumus bahkan mengartikan rumus tersebut dalam bahasa matematika. Selain sulitnya materi, penyebab lainnya adalah matematika disampaikan dengan cara pengajaran yang monoton dan kurang tepat sehingga membuat para siswa merasa bosan.

Berdasarkan data yang diperoleh di kelas X MIA 3 MAN 1 Banjarmasin, hasil belajar siswa siswa masih tergolong pada kategori rendah. Hal tersebut dapat dilihat dari jumlah siswa yang memenuhi KKM hanya sebesar $(56,67 \%)$. Rendahnya hasil belajar siswa salah satunya identifikasikan model pembelajaran yang dilakukan guru yang bersifat konvensional. Siswa lebih bersikap pasif selalu menunggu instruksi dari guru untuk mendengarkan dan mencatat saja, sedangkan pembelajaran akan kurang maksimal jika hanya instruksi yang dilakukan, sehingga perlu sebuah model pembelajaran yang menumbuhkan sikap aktif siswa, terutama dari segi motivasi dan hasil belajar siswa.

Banyak model pembelajaran yang dapat diterapkan oleh guru untuk mengatasi permasalahan-permasalahan di atas. Salah satunya adalah ARIAS (Assurance, Relevance, Interest, Assesment dan Satisfaction). ARIAS merupakan model pembelajaran yang terdiri dari lima komponen teori-teori belajar yaitu Assurance (Percaya Diri), Relevance (Relevansi), Interest (Minat atau Perhatian), Assesment (Evaluasi) dan Satisfaction (Kepuasaan).

Diharapkan dengan diterapkannya model ARIAS ini, siswa akan lebih termotivasi dalam mengikuti pembelajaran karena materi yang disampaikan dalam versi yang mudah dipahami dan diterapkan karena dihubungkan dengan kehidupan sehari-hari yang tak jauh-jauh dari sekitar mereka. Selain itu, adanya proses evaluasi terhadap apa yang sudah mereka pelajari akan mempermudah guru mengetahui lebih cepat mengetahui apakah materi yang disampaikan diterima dengan baik oleh siswa atau tidak.

Pada penelitian ini, model ARIAS akan dikombinasikan dengan pendekatan Problem Based Instruction (PBI). PBI adalah suatu pendekatan dimana pembalajaran yang dilakukan didasarkan pada masalah yang ada. Dalam hal ini siswa dituntut untuk belajar melalui permasalahan yang diberikan oleh guru. Belajar berdasarkan masalah adalah interaksi antara 
stimulus dan respons yang memiliki hubungan dua arah antara belajar dan lingkungan. Lingkungan memberikan masukan kepada siswa berupa bantuan dan masalah. Sedangkan sistem saraf berfungsi menafsirkan bantuan itu secara efektif sehingga masalah yang dihadapi dapat diselidiki, dianalisis serta dicari pemecahannya dengan baik (Sudjana, 2014). Menurut

Arends

(2008), pembelajaran berdasarkan masalah merupakan suatu pendekatan pembelajaran di mana siswa mengerjakan permasalahan yang autentik dengan maksud untuk menyusun pengetahuan mereka sendiri, mengembangkan inkuiri dan keterampilan berfikir tingkat lebih, mengembangkan kemandirian dan percaya diri.

\section{METODE PENELITIAN}

Penelitian ini dirancang dan dilaksanakan dengan menggunakan Penelitian Tindakan Kelas (PTK). Menurut Kunandar (2013), PTK adalah sebuah bentuk kegiatan refleksi diri yang dilakukan oleh para pelaku pendidikan dalam situasi kependidikan untuk memperbaiki rasionalitas dan keadilan tentang: (a) praktik-praktik kependidikan mereka, (b) pemahaman mereka tentang praktik-praktik tersebut, dan (c) situasi di mana praktik- praktik tersebut dilaksanakan. Pada PTK ini menggunakan 4 langkah, yaitu persiapan, pelaksanaan, observasi dan refleksi.

Penelitian dilaksanakan di bulan Oktober 2018. Penelitian dilakukan di kelas $\mathrm{X}$ MIA 3 MAN 1 Banjarmasin. Subjek penelitian siswa kelas X MIA 3 MAN 1 Banjarmasin berjumlah 25 orang yang terdiri 12 orang perempuan dan 13 orang laki-laki, sedangkan objek dalam penelitian ini adalah aktivitas guru, aktivitas belajar siswa, hasil belajar siswa dan respon siswa terhadap pembelajaran yang dilakukan.

Data mengenai hasil belajar kognitif dikumpulkan melalui tes tertulis yang terdiri dari 10 soal pilihan ganda beralasan pada setiap akhir siklus. Kemudian, data aktivitas guru, aktivitas belajar siswa dan hasil belajar afektif siswa dikumpulkan dengan menggunakan teknik nontes yaitu lembar observasi pada setiap pertemuan dan respon siswa dikumpulkan melalui angket respon siswa di akhir siklus II.

Penilaian terhadap aspek pengamatan dalam lembar observasi aktivitas guru menggunakan skor 1-5 disertai rubrik penilaian yang mengukur 8 butir indikator aktivitas guru. Adapun kategori untuk aktivitas guru dapat dilihat pada Tabel 1.

Tabel 1. Kategori Aktivitas Guru

\begin{tabular}{cc}
\hline Skor & Kategori \\
\hline $27-48$ & Sangat Kurang \\
\hline $49-69$ & Kurang \\
\hline $70-91$ & Cukup \\
\hline $92-113$ & Baik \\
\hline $114-135$ & Sangat Baik \\
\hline
\end{tabular}

Penilaian terhadap aspek pengamatan dalam lembar observasi aktivitas belajar siswa menggunakan skor 1-5 disertai rubrik penilaian yang mengukur 4 indikator aktivitas belajar siswa. Adapun kategori 
untuk aktivitas belajar siswa dapat dilihat pada Tabel 2.

Tabel 2. Kategori Aktivitas Belajar Siswa

\begin{tabular}{cc}
\hline Skor & Kategori \\
\hline $6-10$ & Sangat Kurang \\
\hline $11-15$ & Kurang \\
\hline $16-20$ & Cukup \\
\hline $21-25$ & Baik \\
\hline $26-30$ & Sangat Baik \\
\hline
\end{tabular}

Analisis hasil belajar siswa kognitif bertujuan untuk mengetahui tingkat penguasan konsep siswa. Sesuai dengan Kriteria Ketuntasan Belajar (KKM) siswa yang memperoleh nilai lebih atau sama dengan 75 dinyatakan tuntas belajar. Keberhasilan siswa dalam menguasai pembelajaran ditunjukkan dengan nilai ratarata siswa $\geq 75$, daya serap $\geq 75$ dan ketuntasan belajar $\geq 75$. Untuk mendeskripsikan keberhasilan siswa dalam proses pembelajaran dapat dilihat pada Tabel 3

Tabel 3. Kategori Hasil Belajar Kognitif Siswa

\begin{tabular}{cc}
\hline Nilai & Kategori \\
\hline $\mathrm{x}<65$ & Sangat Rendah \\
\hline $65 \leq \mathrm{x}<75$ & Rendah \\
\hline $75 \leq \mathrm{x}<85$ & Cukup \\
\hline $85 \leq \mathrm{x}<95$ & Baik \\
\hline $\mathrm{x} \geq 95$ & Sangat Baik
\end{tabular}

Adaptasi Sudijono (2010)

Penilaian terhadap aspek pengamatan dalam lembar observasi hasil belajar afektif siswa menggunakan skor 1-5 yang mengukur 4 aspek afektif yaitu rasa ingin tahu, teliti, bekerja sama dan menjadi pendengar yang baik. Adapun kategori untuk hasil belajar afektif siswa dapat dilihat pada Tabel 4.

Tabel 4. Kategori Hasil Belajar Afektif Siswa

\begin{tabular}{cc}
\hline Skor & Kategori \\
\hline $5-7$ & Tidak Baik \\
\hline $8-10$ & Kurang \\
\hline $11-13$ & Cukup \\
\hline $14-16$ & Baik \\
\hline $17-20$ & Sangat Baik \\
\hline
\end{tabular}

Adaptasi (Sudjana, 2014) 
Kemudian penilaian respon siswa terhadap pembelajaran dengan model pembelajaran ARIAS terintegrasi pendekatan Problem Based Instruction yang dilakukan dalam lembar angket menggunakan skala likert 1 - 5 yang berisi 10 pertanyaan dengan pilihan jawaban sangat tidak setuju (STS) = 1; tidak setuju $(\mathrm{TS})=2$; ragu-ragu $(\mathrm{RR})=$ 3 ; setuju $(\mathrm{S})=4$; dan sangat setujua $(\mathrm{SS})=$ 5. Berikut kategori respon siswa yang dapat dilihat pada Tabel 5.

Tabel 5. Kategori Respon Siswa

\begin{tabular}{cc}
\hline Rerata Skor & Kategori \\
\hline $10-18$ & Sangat kurang baik \\
\hline $19-26$ & Kurang \\
\hline $27-34$ & Cukup \\
\hline $35-42$ & Baik \\
\hline $43-50$ & Sangat positif \\
\hline
\end{tabular}

Indikator keberhasilan penelitian ini adalah

(1) aktivitas belajar siswa dikatakan berhasil minimal pada kategori baik, (2) aktivitas guru dalam melaksanakan pembelajaran dikatakan berhasil minimal pada kategori baik, (3) hasil belajar kognitif siswa telah optimal jika rata-rata nilai hasil belajar siswa $(\bar{x}) \geq 75$, daya serap (DS) $\geq 75 \%$ dan ketuntasan belajar siswa $(\mathrm{KB}) \geq 75 \%$ dan (4) hasil belajar afektif siswa dalam melaksanakan pembelajaran dikatakan mengalami peningkatan minimal kategori baik.

\section{HASIL DAN PEMBAHASAN Hasil Penelitian}

Hasil evaluasi dan observasi penelitian pada siklus I dan II berupa aktivitas guru, aktivitas belajar siswa, hasil belajar siswa dan respon siswa terhadap pembelajaran dengan model pembelajaran ARIAS terintegrasi pendekatan problem based instruction. Adapun peningkatan skor aktivitas guru pada siklus II jika dibandingkan dengan siklus I dapat dilihat pada Gambar 1.

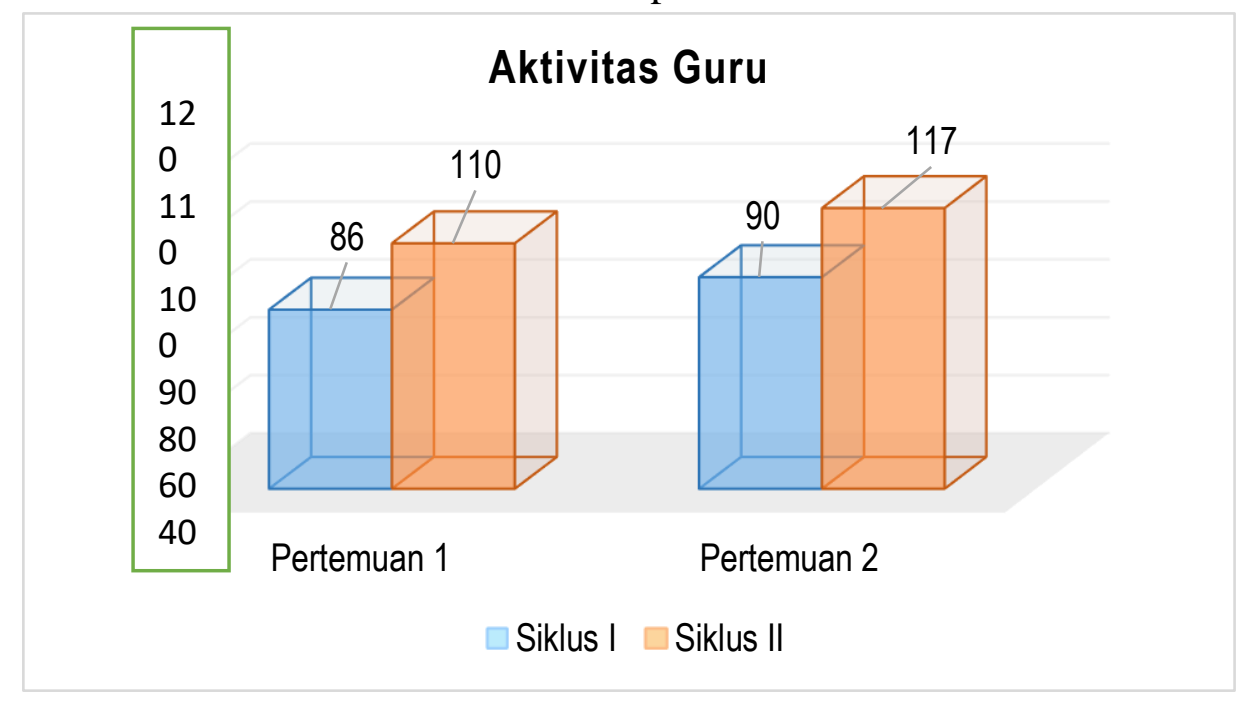

Gambar 1. Peningkatan Skor Aktivitas Guru

Peningkatan skor aktivitas belajar siswa pada siklus II jika dibandingkan dengan siklus I dapat dilihat pada Gambar 2. 


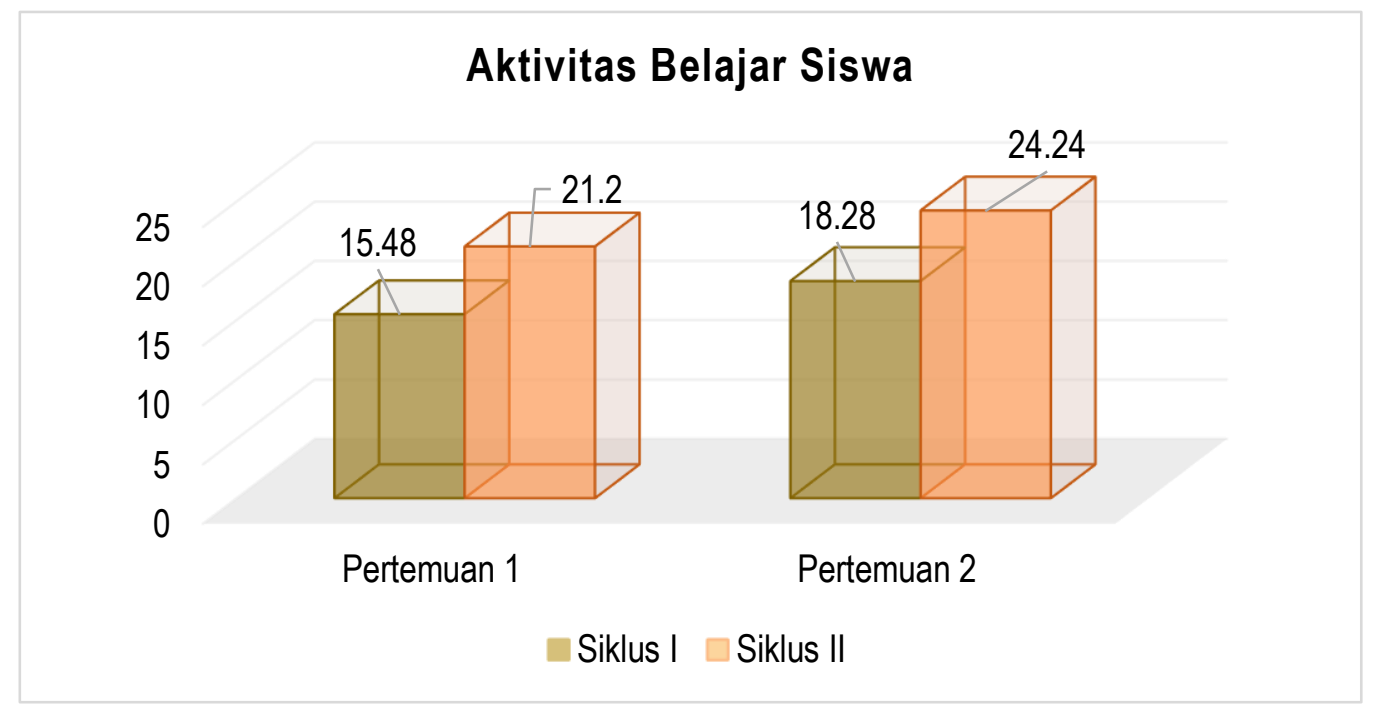

\section{Gambar 2. Peningkatan Skor Aktivitas Belajar Siswa}

Peningkatan skor hasil belajar afektif siswa pada siklus II jika dibandingkan dengan siklus dapat dilihat pada Gambar 3.

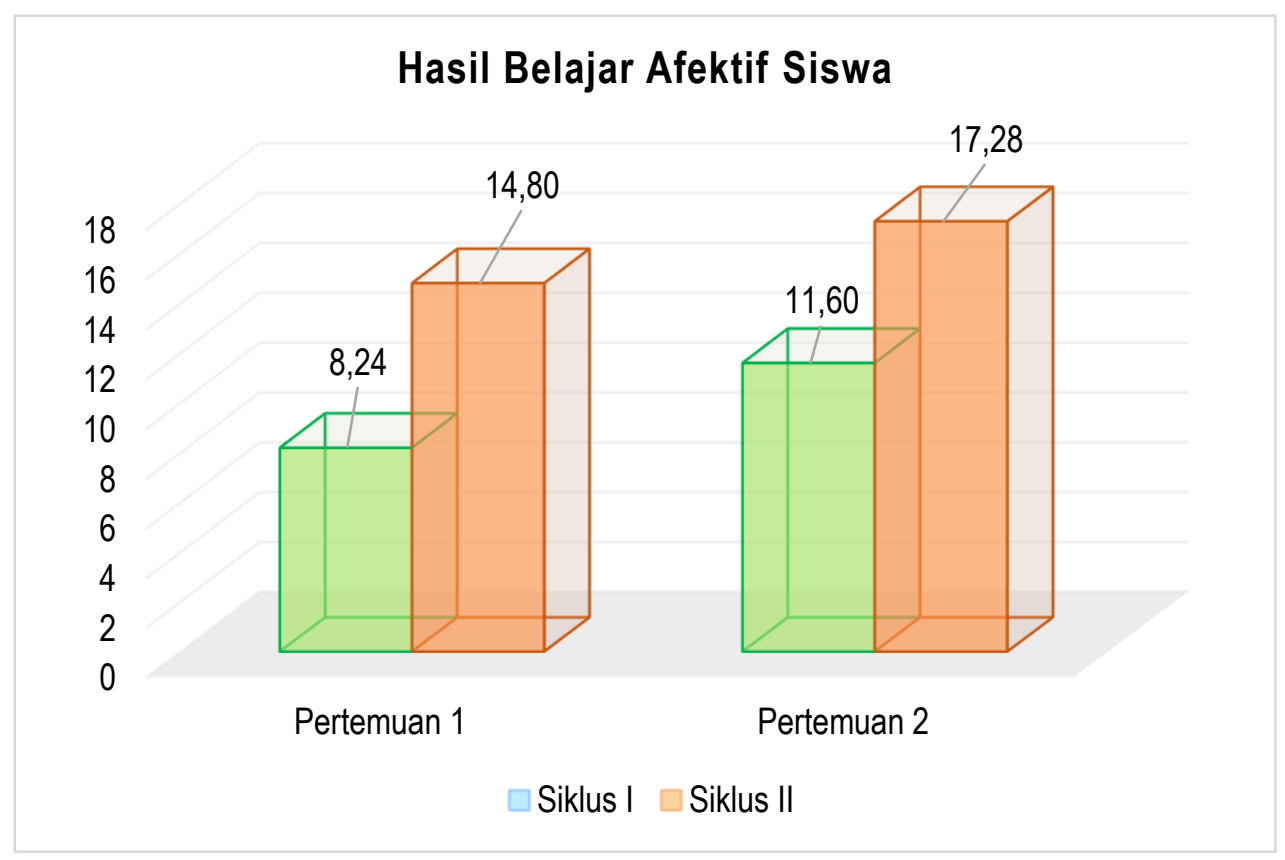

\section{Gambar 3. Peningkatan Skor Hasil Belajar Afektif Siswa}

Peningkatan data hasil belajar kognitif dalam penelitian ini dilihat dari 3 aspek yaitu rata-rata nilai hasil belajar, daya serap dan ketuntasaan belajar. Berikut adalah peningkatan rata-rata nilai hasil belajar kognitif siswa pada siklus II jika dibandingkan dengan siklus I dapat dilihat pada Gambar 4 


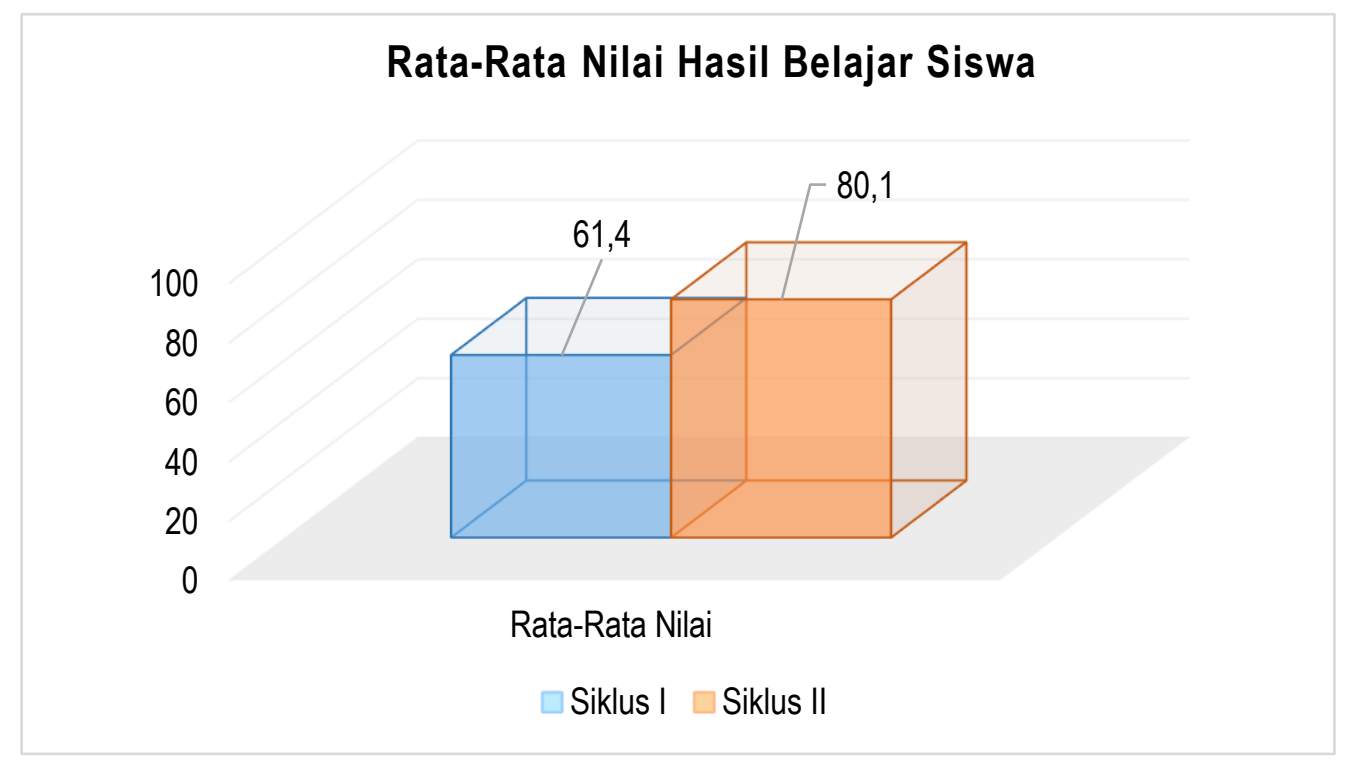

Gambar 4. Peningkatan Nilai Rata-Rata Hasil Belajar

Kemudian, untuk peningkatan daya serap dan ketuntasan belajar pada siklus II jika dibandingkan dengan siklus I yang dapat dilihat pada pada Gambar 5 .

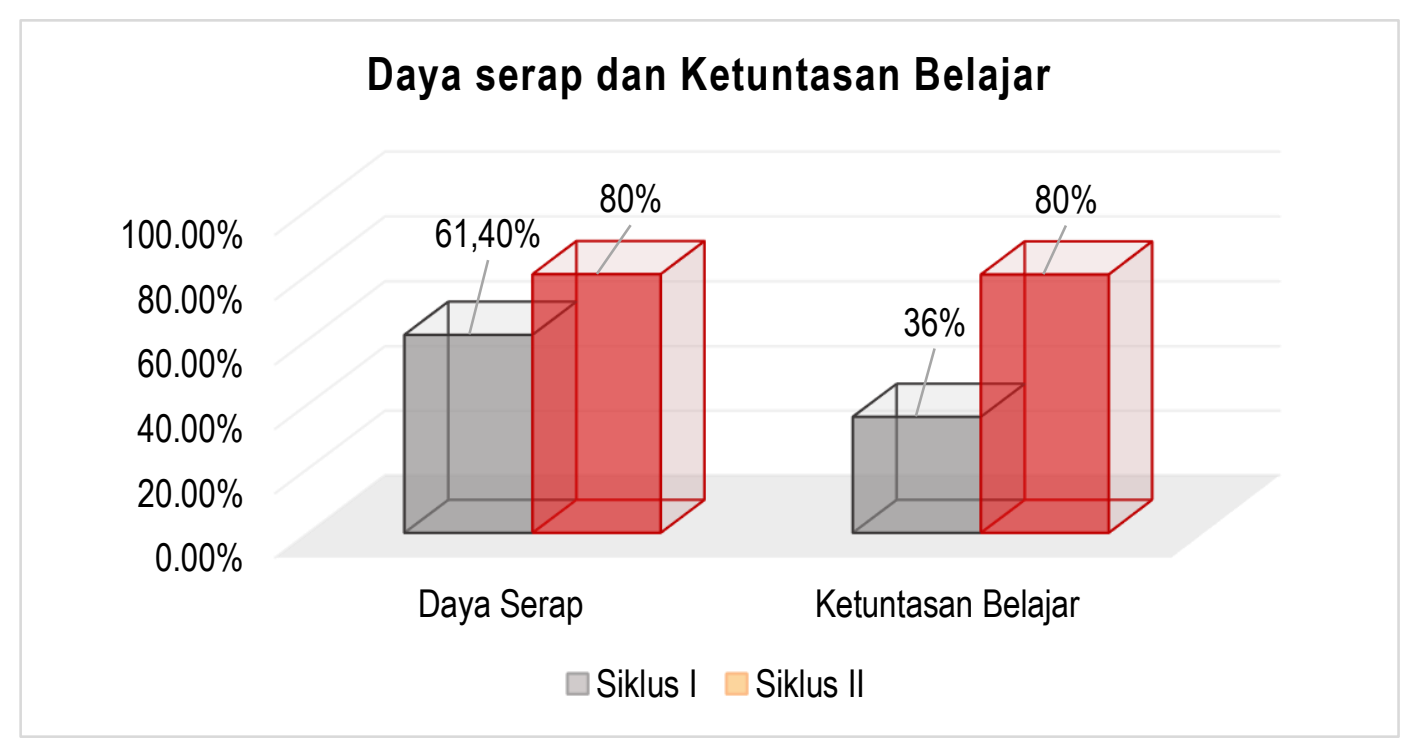

Gambar 5. Peningkatan Daya Serap dan Ketuntasan Belajar 
Angket respon diberikan kepada siswa setelah pembelajaran siklus II. Angket ini bertujuan untuk mengetahui respon 25 orang siswa kelas X MIA 3 MAN 1 Banjarmasin terhadap pembelajaran yang menggunakan model pembelajaran ARIAS terintegrasi pendekatan problem based instruction. Hasil perhitungan menunjukkan $80 \%$ memberikan respon yang baik terhadap penggunaan model pembelajaran ARIAS terintegrasi pendekatan problem based instruction dalam proses pembelajaran.

\section{Pembahasan}

Penelitian tindakan kelas ini dilaksanakan menggunakan model ARIAS terintegrasi pendekatan PBI dalam upaya untuk meningkatkan aktivitas belajar dan hasil belajar siswa. Pembelajaran secara keseluruhan berakhir pada siklus II. Perilaku dan hasil belajar siswa yang diangkat menjadi permasalahan pada penelitian ini mengalami perubahan yang positif. Berdasarkan hasil penelitian di siklus II diperoleh kesepakatan bahwa tindakan belajar yang diambil telah berhasil meningkatkan aktivitas belajar dan hasil belajar siswa.

Secara keseluruhan proses pembelajaran pada siklus I sudah berjalan dengan cukup baik berdasarkan lembar penilaian aktivitas guru. Namun meskipun sudah cukup baik, masih ada beberapa hal yang kurang seperti guru masih kurang dalam pengendalian kelas dan kurang menyeluruhnya bimbingan yang diberikan oleh guru.

Selain itu juga, pembelajaran pada pertemuan pertama ini dilaksanakan memakan banyak waktu sehingga keseluruhan tahap pembelajaran tidak dapat dilaksanakan. Hal ini sejalan dengan Warsono dan Hariyanto (2014) yang menyatakan bahwa kekurangan dalam menerapkan pembelajaran dengan model adalah seringkali memerlukan waktu yang lebih lama daripada pembelajaran dengan model konvensional.

Adapun skor aktivitas guru pada pertemuan pertama ini adalah sebesar 86 dan termasuk kategori cukup baik. Untuk dapat melaksanakan proses pembelajaran selanjutnya, para observer memberikan masukan agar guru lebih intens dalam memberikan bimbingan kepada siswa dan mengatur kondisi kelas. Selain itu, dalam mengatur waktu, guru sebaiknya harus mampu mengatur waktu dengan baik sehingga semua langkah pembelajaran dapat terlaksana dengan baik.

Pada pertemuan kedua siklus I, semua saran dan masukan yang diberikan oleh observer dilaksanakan oleh guru sehingga terjadi peningkatan terhadap skor aktivitas guru menjadi 90 dengan kategori yang sama yaitu cukup baik. Peningkatan terjadi karena berdasarkan hasil observasi, guru menjadi lebih baik dalam segala aspek aktivitas guru dalam melaksanakan pembelajaran seperti pengelolaan kelas, pengelolaan waktu dan lain sebagainya. Secara keseluruhan, skor aktivitas guru meskipun tergolong pada kategori cukup baik dengan rata-rata skor yaitu 88. Namun skor tersebut belum memenuhi standar skor aktivitas guru yang diharapkan oleh guru sebagai peneliti. Oleh karena itu, penilaian aktivitas guru pada siklus I dijadikan bahan refleksi pada siklus II dan penilaian aktivitas guru dilanjutkan ke siklus II.

Pada siklus II ini guru lebih mampu mengelola kelas dan memanagemen waktu sehingga langkah-langkah pembelajaran yang telah direncakanan dapat terlaksana dengan baik. Selain itu, guru juga lebih mampu dalam mengendalikan kelas, 
memotivasi siswa, dan membimbing siswa. Aktivitas guru dalam setiap pertemuan siklus II terus meningkat. Pada siklus II pertemuan pertama skor aktivitas guru adalah 110 dengan kategori baik dan meningkat pada pertemuan kedua siklus II menjadi sebesar 117 dengan kategori yang sama. Dibandingkan dengan siklus I, skor aktivitas guru meningkat sebesar 25,5 poin dari 88 dengan kategori cukup baik meningkat menjadi sebesar 113,5 dengan kategori baik pada siklus II.

Tujuan dari penelitian ini salah satunya adalah meningkatkan aktivitas belajar siswa. Adanya peningkatan aktivitas belajar dapat diketahui dengan melihat apa terjadi peningkatan skor pada setiap indikator yang diamati. Indikator aktivitas belajar yang diamati pada penelitian adalah visual, oral, writing dan mental.

Berdasarkan hasil observasi, aktivitas belajar siswa pada pertemuan pertama siklus I menunjukkan kondisi yang kurang dengan skor 15,48 . Terdapat beberapa hal yang perlu diperbaiki agar terjadi peningkatan aktivitas belajar siswa pada pertemuan selanjutnya. Hal yang perlu diperbaiki adalah masih ada beberapa siswa yang belum bisa dan kebingungan mengikuti pembelajaran dengan model ARIAS terintegrasi pendekatan PBI. Selain itu, siswa kurang termotivasi sehingga kondisi kelas menjadi kurang kondusif.

Untuk terlaksananya proses pembelajaran yang lebih baik pada pertemuan selanjutnya, para observer memberikan saran dan masukan. Berdasarkan saran yang diberikan, guru berusaha lebih kreatif lagi dalam membangun proses pembelajaran yang digunakan agar dapat mentransfer materi dari guru ke siswa dengan lebih baik. Selain itu juga, guru harus lebih bisa mengendalikan kelas agar kelas tetap kondusif dari awal hingga akhir pembelajar.

Adanya upaya perbaikan yang dilakukan oleh guru memberikan pengaruh terhadap aktivitas belajar siswa dimana terjadi peningkatan skor pada pertemuan kedua sebesar 1,80 poin dari 15,48 pada pertemuan pertama menjadi 17,28 pada pertemuan kedua. Secara keseluruhan, aktivitas belajar siswa pada siklus I tergolong cukup baik dengan rata-rata skor sebesar 16,88 . Namun hasil yang diperoleh di siklus I tersebut belum memenuhi standar aktivitas belajar siswa yang diharapkan oleh guru sebagai peneliti. Oleh sebab itu, penilaian aktivitas belajar siswa pada siklus I dijadikan bahan refleksi pada siklus II dan penilaian aktivitas siswa dilanjutkan ke siklus II.

Dengan memperhatikan hasil observasi aktivitas siswa pada siklus I, maka pelaksanaan pembelajaran di siklus II lebih ditingkatkan dengan memperbaiki kekurangan-kekurangan selama proses pembelajaran siklus I. Hal-hal yang dirasa belum optimal pada aktivitas guru juga diperbaiki sehingga diharapkan dapat berdampak pada meningkatnya aktivitas siswa.

Secara keseluruhan dari tahap awal, inti dan akhir pembelajaran aktivitas siswa tergolong baik. Siswa terlihat lebih termotivasi dalam pembelajaran. Siswa mulai aktif berdiskusi dengan kelompoknya, siswa juga terlihat aktif dalam mengajukan pertanyaan-pertanyaan ketika mereka mengalami kesulitan atau ada materi yang belum mereka pahami. Hal ini disebabkan karena siswa sudah mulai terbiasa dengan pola pembelajaran yang dilaksanakan oleh guru. Selain itu, peningkatan skor aktivitas siswa terjadi dikarenakan siswa lebih 
termotivasi dalam mengikuti pembelajaran dengan menggunakan model ARIAS terintegrasi pendekatan PBI. Pada saat siswa termotivasi, maka siswa akan menjadi aktif dalam kegiatan pembelajaran dan suasana pembelajaran cenderung lebih kondusif.

Jika dilihat pada setiap siklus maka aktivitas siswa dari siklus I ke siklus II mengalami peningkatan dimana pada siklus I rata-rata skor 16,88 dengan kategori cukup baik meningkat pada siklus II menjadi 22,72 dengan kategori baik. Adanya peningkatan di setiap siklusnya menunjukkan bahwa model ARIAS terintegrasi pendekatan PBI dapat meningkatkan aktivitas belajar siswa. Hal ini dikarenakan model ARIAS merupakan model paket lengkap dimana di dalam model ARIAS telah tercakup usaha-usaha yang harus dilakukan oleh guru dalam menanamkan motivasi dan rasa percaya diri siswa seperti mengaitkan materi yang mereka pelajari dengan kehidupan sehari-hari mereka. Menurut Wardi (2017) siswa akan terdorong mempelajari sesuatu jika apa yang mereka pelajari memiliki relevansi dengan kehidupan mereka.

Faktor lain adalah pendekatan PBI yang digunakan dimana dalam pendekatan PBI siswa melakukan eksplorasi dan problem solving yang mana hal itu meningkatkan kemampuan mental dalam memecahkan masalah. Kemudian pengajuan pertanyaan dan masalah yang diberikan berpangkal pada kehidupan nyata siswa di sekolah. Tentunya hal ini akan mendorong siswa agar lebih termotivasi dan lebih aktif dalam mengikuti proses pembelajaran.

Hasil yang diperoleh ini sejalan dengan hasil penelitian Desyana dan Sabirin (2017) menyatakan bahwa dengan menggunakan model pembelajaran ARIAS dapat meningkatkan aktivitas siswa dalam belajar. Demikian pula penelitian Farina, Saukani dan Salminawati (2018) dengan menggunakan pendekatan PBI, siswa memiliki aktivitas belajar yang tinggi daripada sebelum mengikuti pembelajaran.

Berdasarkan hasil penelitian, hasil belajar kognitif siswa materi sistem persamaan tiga variabel pada siklus I dengan menerapkan model pembelajaran ARIAS terintegrasi pendekatan PBI mengalami peningkatan dari kondisi awal sebelum diterapkan model tersebut. Pada siklus I ratarata nilai sebesar 61,40 , daya serap sebesar $61,40 \%$ pada dan ketuntasan belajar mengalami peningkatan sebesar $36 \%$.

Pada pelaksanaan siklus II terjadi peningkatan hasil belajar kognitif dari siklus I. Hal ini dapat dilihat dari rata-rata nilai siswa yang meningkat dari 61,40 pada siklus I menjadi 80,1 pada siklus II. Kemudian, data serap yang meningkat dari $61,40 \%$ pada siklus I menjadi $80,1 \%$ pada siklus II. Selain itu terjadi peningkatan ketuntasan siswa dimana dari $36 \%$ pada siklus I menjadi $80 \%$ pada siklus II.

Penerapan model pembelajaran ARIAS terintegrasi pendekatan PBI membuat siswa menjadi lebih aktif dalam mengikuti proses pembelajaran. Hal ini karena dalam proses pembelajaran guru aktif untuk bertanya dimana pertanyaan disusun bertingkat dari yang mudah ke sulit dengan tujuan memancing keberanian dan tumbuhnya keaktifan siswa. Selain itu, adanya proses mencari konsep sendiri melalui kegiatan penyelidikan sehingga pengetahuan yang diperoleh siswa tidak hanya berasal dari transfer informasi dari guru terhadap siswa dan pengetahuan yang diperoleh menjadi lebih bermakna karena siswa memperoleh apa yang mereka pelajari dengan sendiri sehingga ingatan mereka lebih 
kuat akan materi tersebut sehingga meningkatnya hasil belajar siswa.

Hal ini sesuai dengan penelitian Lestari, Nursalam dan Mardhiah (2016) yang menyatakan bahwa penerapan model pembelajaran ARIAS terintegrasi pendekatan PBI dalam proses berpengaruh positif pada hasil belajar siswa. Demikian pula, penelitian Agus (2018) menyimpulkan bahwa penerapan pendekatan PBI dalam proses pembelajaran dapat meningkatkan hasil belajar siswa.

Selain hasil belajar kognitif, penelitian ini juga menilai hasil belajar aspek afektif siswa. Aspek afektif siswa yang dinilai dalam penelitian ini adalah jujur, percaya diri, displin dan bertanggung jawab. Aspek afektif siswa dinilai dalam setiap pembelajaran berlangsung menggunakan lembar observasi yang telah disertai rubrik penilaian.

Hasil belajar afektif siswa secara keseluruhan pada siklus I sebesar 10,11 dengan kategori cukup baik. Karena hasil yang diperoleh masih belum sesuai dengan target yang diinginkan, maka diadakan pembelajaran lanjut pada siklus II. Pada siklus II, diadakan perbaikan sehingga terjadi peningkatan pada aspek afektif menjadi sebesar 14,01 dengan kategori baik.

Hal ini dapat dikatakan bahwa model pembelajaran ARIAS terintegrasi pendekatan PBI memberikan pengaruh positif terhadap hasil belajar afektif siswa. Hal ini sejalan dengan penelitian Pratiwi (2014) yang menyatakan bahwa adanya peningkatan pada sikap peserta didik menunjukkan bahwa melalui proses pembelajaran dengan model ARIAS terintegrasi pendekatan PBI dapat menyebabkan siswa memiliki antusias dan motivasi terhadap proses pembelajaran, sehingga sikap yang diharapkan dimiliki oleh peserta didik dapat muncul dalam proses pembelajaran.

Berdasarkan hasil penilaian respon
siswa terhadap pembelajaran dengan menggunakan model pembelajaran ARIAS terintegrasi pendekatan PBI, sebagian besar siswa memberikan respon yang baik. Respon baik yang diberikan siswa ditunjukan dengan banyaknya siswa yang memberikan respon sangat baik dan baik dibandingkan dengan respon cukup, tidak baik dan sangat tidak baik.

Respon baik siswa tersebut menandakan bahwa pembelajaran dengan menggunakan model pembelajaran ARIAS terintegrasi pendekatan PBI membuat siswa menjadi lebih tertarik dan termotivasi untuk mengikuti pembelajaran dan memudahkan siswa memahami materi yang diajarkan.

Berdasarkan pembahasan di atas maka penelitian ini telah menjawab hipotesis tindakan yang ada bahwa penggunaan model pembelajaran ARIAS terintegrasi pendekatan PBI berhasil memperbaiki proses pembelajaran sehingga dapat meningkatkan kemampuan mendengarkan siswa dan hasil belajar siswa (kognitif dan afektif) pada siklus I dan siklus II. Selain itu, siswa juga menunjukkan respon yang baik terhadap pembelajaran dengan menggunakan model pembelajaran ARIAS terintegrasi pendekatan PBI. Dengan penerapan model ARIAS terintegrasi pendekatan PBI, siswa merasa lebih mudah mengerti dan lebih memahami materi yang diajarkan. Siswa dapat menjawab pertanyaan dalam tes mendengarkan dan hasil belajar dengan lebih mudah dan juga pembelajaran yang dapat terlaksana dengan lebih menyenangkan dan bermakna. 


\section{PENUTUP}

Berdasarkan hasil penelitian yang telah dilakukan di kelas $\mathrm{X}$ MIA 3 MAN 1 Banjarmasin tahun pelajaran 2018/2019 dapat disimpulkan bahwa: (1) aktivitas guru dalam pembelajaran menggunakan model pembelajaran ARIAS terintegrasi pendekatan PBI mengalami peningkatan kategori cukup baik pada siklus I menjadi baik pada siklus II, (2) aktivitas belajar siswa dalam pembelajaran menggunakan model pembelajaran ARIAS terintegrasi pendekatan PBI mengalami peningkatan kategori cukup baik pada siklus I menjadi baik pada siklus II, (3) hasil belajar afektif siswa dalam pembelajaran menggunakan model pembelajaran ARIAS terintegrasi pendekatan PBI mengalami peningkatan kategori cukup baik pada siklus I menjadi baik pada siklus II, (4) hasil belajar kognitif siswa dalam pembelajaran menggunakan model pembelajaran ARIAS terintegrasi pendekatan PBI mengalami peningkatan dari siklus I yaitu 61,40 dengan kategori rendah menjadi 80,10 pada siklus II dengan kategori baik dan (5) Siswa memberikan respon yang baik terhadap pembelajaran dengan model ARIAS sebagai modelnya dan pendekatan PBI sebagai pendekatannya.

\section{DAFTAR RUJUKAN}

Arends, R. (2008). Learning to Teach. Yogyakarta: Pustaka Pelajar.

Agus, A., P. (2018), Pengaruh Model Pembelajaran Problem Based Instruction Terhadap Hasil Belajar Ditinjau Dari Gaya Belajar Siswa. Jurnal Penelitian Pendidikan IPA (JPPIPA). 4(1): 60.

Desyana, M dan Sabirin, M. (2017). Efektivitas Model Pembelajaran ARIAS pada Materi Penjumlahan dan Pengurangan Bilangan Bulat. Jurnal Tarbiyah. 6(1): 50.

Farina, A., Saukani dan Salminawati. (2018). Efektifitas Pendekatan Problem Based Instruction (PBI) terhadap Motivasi Belajar dan Hasil Belajar Siswa Pada Mata Pelajaran Di SMP Ar-Rahman Percut. Jurnal AT-TAZZAKI. 2(1): 43.

Kunandar. (2013). Penilaian Autentik (Penilaian Hasil Belajar Peserta Didik Berdasarkan Kurikulum 2013). Jakarta: Rajawali Press.

Lestari, A., Nursalam dan Mardhiah. (2016). Pengaruh Model Pembelajaran ARIAS (Assurance, Relevance, Interest, Assesment, Satisfication) Terhadap Hasil Belajar Matematika Siswa Kelas VII SMPN 1 Sungguminasa Kab. Gowa”. Jurnal Matematika dan Pembelajaran (Mapan). 5(1): 122.

Pratiwi, Y. (2014). Pelaksanaan Model Pembelajaran ARIAS Terintegrasi PBI di Kelas X SMA Negeri 5 Surakarta Tahun Pelajaran 2013/2014. Jurnal Pendidikan UNS. 3(2): 50-58.

Sudjana, N. (2014). Penilaian Hasil Proses Belajar Mengajar. Bandung: Remaja Rosdakarya.

Sudijono, A. (2010). Pengantar Statistik Pendidikan. Jakarta: Rajawali Pers.

Wardi. (2017). Meningkatkan Prestasi Belajar melalui Pemberian Apersepsi, Motivasi dan Demonstrasi serta Penggunaan Alat Peraga Pelajaran IPA di Kelas IV. Jurnal Pendidikan dan Ilmu Pendidikan. 17(1), hlm.186.

Warsono, dan Hariyanto. (2014). Pembelajaran Aktif: Teori dan Asesmen. Bandung: PT. Remaja Rosdakarya. 
Jurnal PTK \& Pendidikan

Vol. 5, No. 2, Hal (49-60) 